\title{
Articulo Original / Original Article \\ Physiological and metabolic alterations in basil (Ocimum basilicum L.) varieties under distinct soil water levels
}

\author{
[Alteraciones fisiológicas y metabólicas en variedades de albahaca (Ocimum basilicum L.) \\ bajo distintos niveles de agua del suelo]
}

\author{
Larissa Santos Castro ${ }^{1}$, Daniel Andrés Villegas Hurtado ${ }^{1}$, Adriene Aparecida Silva ${ }^{2}$, Danúbia Aparecida Costa Nobre ${ }^{3}$, \\ Geraldo Humberto Silva ${ }^{2} \&$ Willian Rodrigues Macedo ${ }^{1}$ \\ ${ }^{1}$ Crop Physiology and Metabolism Lab, Institute of Agricultural Sciences, \\ Federal University of Viçosa, Campus Rio Paranaíba, Brazil \\ ${ }^{2}$ Laboratory for the Development of Natural Agrochemicals, Instituto de Ciências Exatas, \\ Federal University of Viçosa, Campus Rio Paranaiba, Brazil. \\ ${ }^{3}$ Laboratory of Processed Products of Plant Origin, \\ Federal University of Jequitinhonha and Mucuri Valleys, Campus Diamantina, Brazil
}

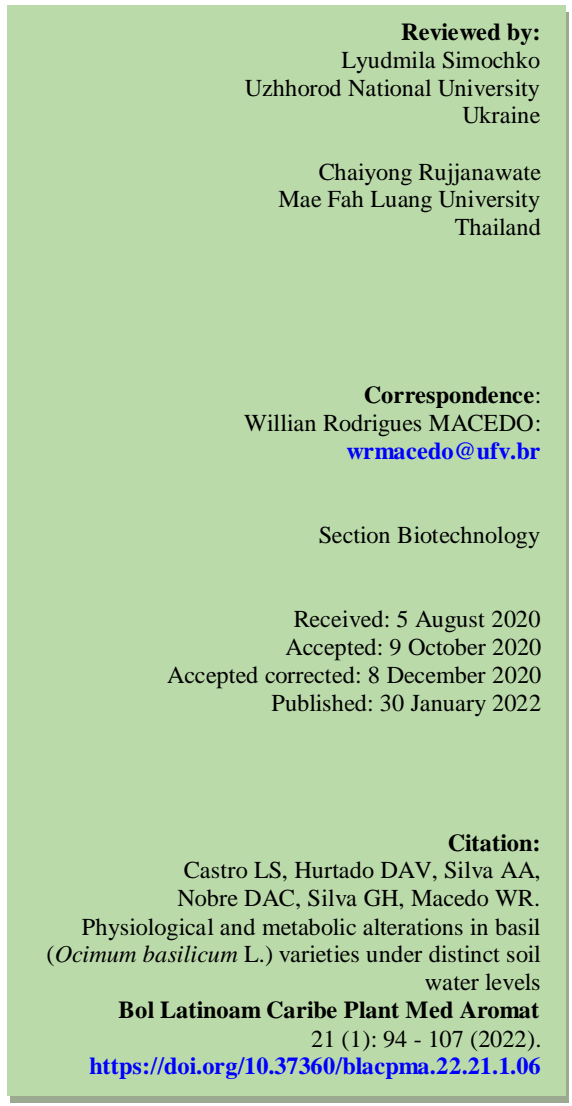

Abstract: Basil (Ocimum basilicum L.) is a medicinal species used in several areas, such as food, medicines and cosmetics, and the understanding of its physiological behavior under environmental conditions is of paramount importance for the improvement of cultivation methods. The objective of this study was to evaluate the influence of different water availability under physiological, biochemical and metabolic characteristics, in three distinct genotypes: 'Alfavaca basilicão', 'Gennaro de menta' and 'Grecco à palla', during two different phenological stages (vegetative and reproductive). It was found that the water deficit promotes physiological changes to tolerate water stress, and the studied genotypes have different routes to achieve this physiological tolerance, which culminates in a distinct accumulation of metabolites in plants, and can be considered interesting if the final product is the production of essential oils.

Keywords: Irrigation; Plant metabolism; Essential oils; Medicinal plants; Ocimum basilicum.

Resumen: La albahaca (Ocimum basilicum L.) es una planta medicinal utilizada en varias áreas: alimenticia, medicinal e industria cosmética; es de suma importancia el entendimiento de su comportamiento fisiológico bajo diferentes condiciones ambientales con el fin de mejorar los procesos del cultivo. El objetivo de este estudio fue evaluar la influencia de diferentes disponibilidades hídricas en las características fisiológicas, bioquímicas y metabólicas en tres genotipos de albahaca: "Alfavaca basilicão", "Gennaro de menta" y "Grecco à palla" durante dos etapas fenológicas (vegetativa y reproductiva). Fue encontrado que el déficit hídrico promueve cambios fisiológicos con el fin de tolerar el estrés hídrico. Los genotipos estudiados presentaron diferentes rutas para alcanzar esta tolerancia fisiológica, la cual culmina con distintas acumulaciones de metabolitos en las plantas, y puede ser considerado interesante si el producto final es la producción de aceites esenciales.

Palabras clave: Riego; Metabolismo vegetal; Aceites esenciales; Plantas medicinales; Ocimum basilicum 


\section{INTRODUCTION}

Basil (Ocimum basilicum L.) stands out as an important medicinal and aromatic plant, thanks to the main components (linalool and eugenol) present in its essential oil (Dou et al., 2018; Dou et al., 2019), with multiple uses from formulated for agricultural applications to cosmetic use (Dorni et al., 2017). However, all its productive potential of biomass and chemical compounds is strongly conditioned by the genotypes used and by the environmental conditions of cultivation (Paton \& Putievsky, 1996; Patel et al., 2016).

Among the environmental conditions that most impact basil, the availability of water is a major factor for this species, studies show that water stress negatively affects physiological processes and, consequently, plant growth (Afkari, 2018). The water deficit restricts the stomatal opening, by reducing the water potential in the leaf and its stomatal conductance, resulting in the blockage of $\mathrm{CO}_{2}$ flow, reduction in the accumulation of photoassimilates and reducing productivity (Basu et al., 2016, Bianchi et al., 2016).

For Ocimum cultivation, water stress has deleterious effects on physiological, morphological and biochemical characteristics (Pirbalouti et al., 2017), however, since it is an aromatic plant, many oils of commercial interest are produced in secondary metabolism routes, and in basil, the water deficit causes increases in these constituents to a certain point of deficient water control (Omidbaigi et al. 2003).

This research had as main objective to evaluate the effect of different levels of water availability on the physiological, biochemical and metabolic performance, in three varieties of $O$. basilicum (Alfavaca Basilicão, Gennaro de Menta and Grecco à palla) during the vegetative and reproductive phase of the plants.

\section{MATERIAL AND METHODS \\ Experiment location and conditions}

The research was conducted in a greenhouse and in the Plant Production Physiology and Metabolism laboratory (Laboratório de Fisiologia e Metabolismo da Produção Vegetal - LAFIMEPRO), both at the Federal University of Viçosa - Rio Paranaíba Campus, from September 2018 to February 2019, covering a period of 125 days. The plants of Ocimum basilicum L. were obtained through propagation via seeds (Isla Sementes ${ }^{\circledR}$, Brazil), of three varieties of basil (Alfavaca basilicão, Gennaro de menta and Grecco à palla). The seeds were grown in polyethylene trays of 128 cells, filled with commercial substrate (Plantmax ${ }^{\circledR}$ ), and after 28 days of planting (DAP), the plants were transplanted into plastic pots $\left(5 \mathrm{dm}^{3}\right)$ filled with clayey oxisol, with the following chemical characteristics: Organic Matter: $26 \mathrm{~g} \mathrm{dm}^{-3}$; P: $8 \mathrm{mg} \mathrm{dm}^{-3}$; K: 2,2 mmol dm $\mathrm{m}^{-3}$; $\mathrm{Ca}: 33$ mmol dm${ }^{-3}$; $\mathrm{Mg}$ : $10 \mathrm{mmol} \mathrm{d}^{-3}$; $\mathrm{pH}$ : 5,3. Fertilization was carried out during transplanting with $30 \mathrm{~g} \mathrm{~m}^{-2}$ of fertilizer in formulation 08-28-16 (N-P-K). Cultivation activities were carried out in accordance with the recommended practices for culture.

The irrigation of the pots was performed according to the maximum water retention capacity of the soil, proposed by Fernandes and Syke (1968). $80 \%$ of field capacity was considered an adequate condition for water volume and $60 \%$ of field capacity was a condition of moderate scarcity. From planting to the imposition of stresses, the pots were kept under irrigation of $80 \%$ of the field capacity, with daily monitoring to replace the water evapotranspiration.

The experiment was divided into two stages, with an evaluation of the behavior of the plants during the vegetative phase (75 to $78 \mathrm{DAP}$ ) and in the flowering stage (120 to 123 DAP). Both stages were evaluated under two water availability regimes, being $60 \%$ (moderate stress) and $80 \%$ (no stress) of the water capacity in the soil.

\section{First Stage \\ Relative water content $(R W C)$}

It was determined during the vegetative and flowering stages. 10 leaf discs were removed and the fresh weight (FW) was recorded immediately. The leaf discs were kept in $20 \mathrm{~mL}$ of water for 24 hours and, subsequently, the wet weight (WW) was obtained. Then, the plant material was dried for 72 hours at $70^{\circ} \mathrm{C}$ in an oven and the dry weight (DW) was recorded. The RWC was calculated using the formula:

$$
R W C(\%)=\left[\frac{F W-D W}{W W-D W}\right] x 100
$$

\section{Total soluble protein (TSP)}

It was determined during the vegetative stage using the method described by Bradford (1976). The reaction was prepared with $20 \mu \mathrm{L}$ of the protein 
extract, added to $3.0 \mathrm{~mL}$ of Bradford's reagent, (LGC Biotecnologia, Cotia, SP, Brazil). The reading was performed on a spectrophotometer at $595 \mathrm{~nm}$, and the TSP concentration was calculated from the standard curve prepared with bovine serum albumin (BSA). The results obtained were expressed in $\mathrm{mg}$ of protein per $\mathrm{g}^{-1}$ of fresh matter.

\section{Activity of antioxidant enzymes and proline}

The quantification of the activity of ascorbate peroxidase (APX) and catalase (CAT) were evaluated in a vegetative stage. APX activity was determined by the method described by Nakano and Asada (1981), and the results were expressed in $\mu$ mol APX $\mathrm{min}^{-1} \mathrm{mg}^{-1}$ TSP. CAT activity was determined by the method described by Havir and McHale (1987), and the results were expressed in $\mu \mathrm{mol} \mathrm{CAT} \mathrm{min}^{-1} \mathrm{mg}^{-1}$ TSP. The proline content was quantified according to Bates et al. (1973) during the vegetative and flowering stages.

\section{Photosynthetic pigments content}

The quantification of chlorophyll $a$ (Chl. A), chlorophyll $b$ (Chl. B), total chlorophyll (Chl. Total) and carotenoids (Car.) were evaluated in vegetative stage and flowering through solvent extraction $(80 \%$ acetone), modified according to Macedo et al. (2013). The plant material was placed in plastic tubes $(50 \mathrm{~mL})$ containing an $80 \%$ (v/v) acetone solution and were kept in the dark for 72 hours. Subsequently, the extracts were read on a spectrophotometer (SP-2000 UV Spectrum) at absorbances (Witham et al., 1971) of 663,645 and $470 \mathrm{~nm}$, to determine chlorophylls $a$, $b$ and carotenoids, respectively. The values obtained were used to calculate the results, and these were expressed in milligrams per gram of pigment in fresh leaf tissue $\left(\mathrm{mg} \mathrm{g}^{-1}\right)$.

\section{Essential oils}

It was performed using the hydrodistillation method, using a CLEVENGER apparatus, using $20 \mathrm{~g}$ of the dry leaves of plants in a vegetative stage mixed in $400 \mathrm{~mL}$ of distilled water, the extraction time was 90 minutes, after the first drop. The chemical analysis of essential oils was by gas chromatography coupled to mass spectrometry (GC-MS), in a QP2010 model equipment (Shimadzu). The compounds were identified by comparing the mass spectra with those in the NIST library, visual interpretation of the mass spectra and comparing the retention indices. The relative percentage of each compound was calculated using the ratio between the area of each peak and the total area of all constituents in the sample.

\section{Second Stage}

It consisted of the reanalysis of the RWC, proline and photosynthetic pigments, as previously presented, in addition to analysis of gas exchange and extravasation of electrolytes in leaf tissues for the flowering stage.

\section{Gas exchange}

The evaluations included the measurement of the $\mathrm{CO}_{2}$ assimilation rate $(A)\left(\mu \mathrm{mol} \mathrm{m} \mathrm{m}^{-2} \mathrm{~s}^{-1}\right)$, leaf transpiration (E) $\left(\mathrm{mmol}\right.$ of $\left.\mathrm{H}_{2} \mathrm{O} \mathrm{m}^{-2} \mathrm{~s}^{-1}\right)$ and stomatal conductance ( $g s)\left(\mathrm{mmol} \mathrm{m} \mathrm{m}^{-2} \mathrm{~s}^{-1}\right)$. In possession of these data, the water use efficiency $(A / E)\left[\left(\mu \mathrm{mol} \mathrm{m}^{-2} \mathrm{~s}^{-1}\right)\left(\mathrm{mmol} \mathrm{H}_{2} \mathrm{O}\right.\right.$ $\left.\left.\mathrm{m}^{-2} \mathrm{~s}^{-1}\right)^{-1}\right]$ was calculated. The measurements took place during the three days of water restriction, from 9:00 am to 10:00 am, with the gas exchange analyzer, model LI-6400 XT (Li-Cor Biosciences, USA), coupled to a fluorometer, with photon flow density of $900 \mu \mathrm{mol} \mathrm{m}^{-2} \mathrm{~s}^{-1}$. No gas exchange assessments were carried out for the Gennaro de menta variety, due to the reduced size of the leaf area.

\section{Electrolyte leakage (EL)}

The method proposed by Blum and Ebercon (1981), adapted by Silveira et al. (2001). The electrical conductivity (L1) of a distilled water solution $(20 \mathrm{~mL})$ containing 10 leaf discs immersed for 24 hours was determined. The samples remained in a water bath at $100^{\circ} \mathrm{C}$ for one hour and, subsequently, the electrical conductivity of the solution was measured again (L2). The quantification (\%) of the extravasation of electrolytes was obtained using the formula:

$$
E L(\%)=\left(\frac{L 1}{L 2}\right) \times 100
$$

\section{Statistical analysis}

The experimental design used was completely randomized, in a $3 \times 2$ factorial scheme, being: three varieties of basil - Gennaro de Menta, Grecco à palla and Alfavaca basilicão - and two water levels - $60 \%$ (moderate stress) and $80 \%$ (no stress) of maximum water retention capacity in the soil -, with four repetitions. Subsequently, the data obtained were subjected to analysis of variance (ANOVA) and comparisons between averages by the Student- 
Newman-Keuls test (SNK) at 5\% probability, using the statistical program Speed Stat (Carvalho \& Mendes, 2017). While for the analysis of essential oils, the means were evaluated by principal component analysis (PCA), with the PAST software (Hammer et al., 2001).

\section{RESULTS}

\section{Relative water content}

The results obtained for the relative water content (RWC) in the vegetative phase (Figure No. 1), demonstrated that at the level of $80 \%$ and $60 \%$ of water in the soil there was no significant difference between the varieties. However, the Gennaro de menta variety, when subjected to $60 \%$ water level, significantly decreases the RWC. For the RWC in the flowering phase (Figure No. 1), there was no significant difference between the varieties at the level of $80 \%$ of water, however at the level of $60 \%$ of water in the soil, the varieties showed different behavior, the Gennaro de menta being the material that best managed to stabilize the water content in the leaves, while the Alfavaca basilicão and Grecco à palla showed significant reductions to the detriment of the water deficit.

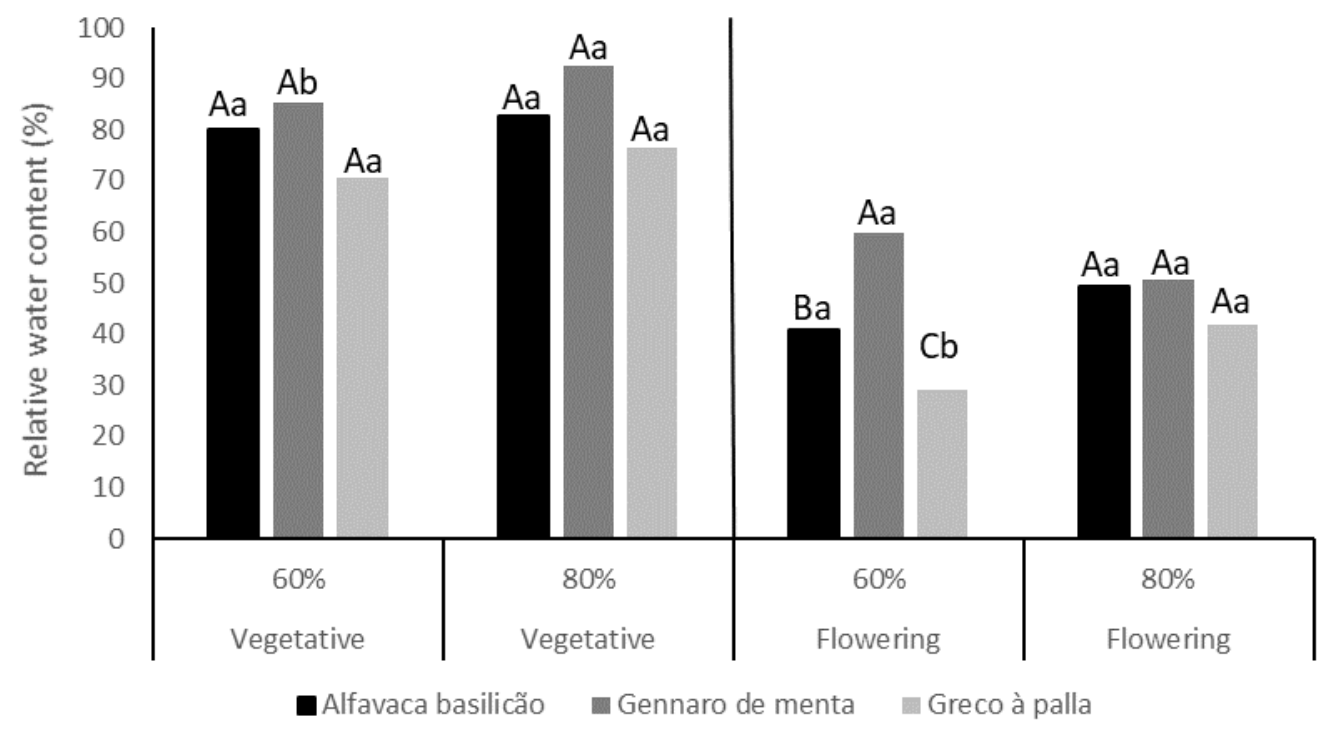

Figure No. 1

Relative water content in leaves at 78 (A) and 123 (B) DAP. Averages followed by the same letter do not differ statistically by the SNK test (5\%). Uppercase letters compare the averages within the water levels, and lowercase letters compare the averages within the varieties, at the two evaluated stages

\section{Photosynthetic pigments}

During the vegetative stage, there was no significant difference between the varieties in the two water levels for the variable chlorophyll $a$ content (Figure No. 2A), however the varieties Gennaro de menta and Grecco à palla showed lower contents at the level of $60 \%$ water. As for the content of chlorophyll $b$ (Figure No. 2B), in the vegetative phase, the water deficit reduced the content in the varieties Alfavaca basilicão and Grecco à palla when compared to Gennaro de menta. In the flowering phase, the opposite occurred, with the Gennaro de menta variety having a lower chlorophyll content than the other varieties and with itself at $80 \%$ water level (Figure No. 2). And when analyzing the total chlorophyll content (Figure No. 2C), in the vegetative phase, it was found that the moderate stress decreased significantly for Grecco à palla, while for plants that were not subjected to stress, there were no changes in the content. In the flowering stage, the Gennaro de menta variety showed a reduction in its total chlorophyll at the level of $60 \%$ of water in the soil, when compared with the other varieties and with the level of $80 \%$ of water in the soil. As for the

Boletín Latinoamericano y del Caribe de Plantas Medicinales y Aromáticas / 97 
carotenoid content (Figure No. 2D), it was observed significant differences in the vegetative phase for Grecco à palla, with significant reductions when compared between water levels, as in cultivars, while in the flowering stage the Gennaro de menta variety showed lower content than the other varieties and when compared to the level of $80 \%$ of water in the soil. It was found that the levels of photosynthetic pigments were influenced by the water deficit both in the vegetative phase and in the flowering phase, indicating the flexibility of each variety under the two water levels.
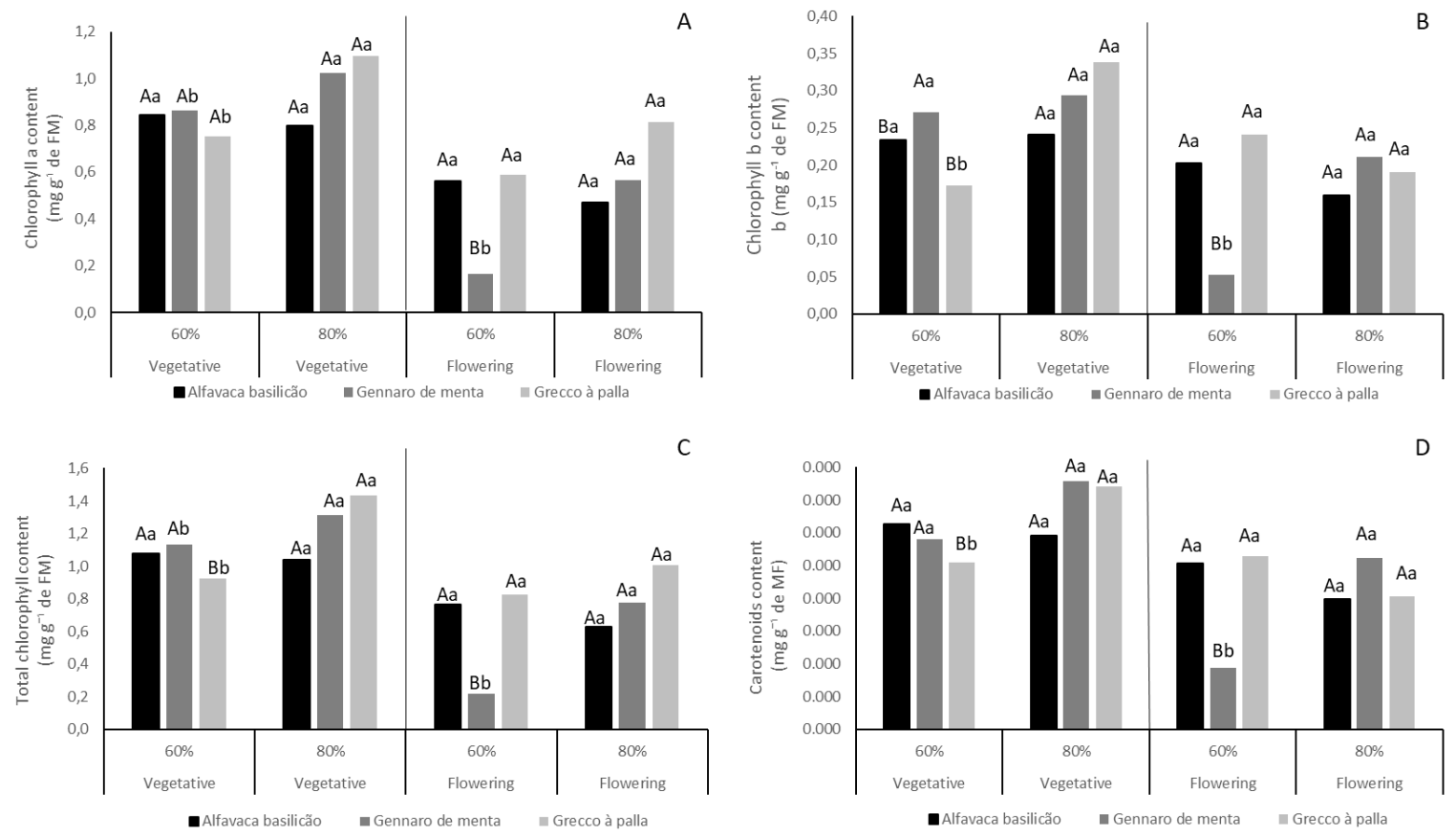

Figure No. 2

Content of photosynthetic pigments, chlorophyll a (A), chlorophyll b (B), total chlorophyll (C) and carotenoids (D), in basil leaves at 78 DAP and 123 DAP. Averages followed by the same letter do not differ statistically by the SNK test (5\%). Uppercase letters compare the averages within the water levels, and lowercase letters compare the averages within the varieties, at the two evaluated stages

\section{Total soluble protein, antioxidant enzymes and proline}

For the content of total soluble proteins (Figure No. $3 \mathrm{~A})$, the results did not show significant interaction, between the water levels and the varieties under study, however, the Gennaro de menta variety showed a significant reduction in the content of total soluble proteins when submitted to the level $80 \%$ water in the soil. In the analysis of the antioxidant enzymes APX (Figure No. 3B) and CAT (Figure No. $3 \mathrm{C}$ ) it is noted that the enzymes have their activity increased for the varieties Alfavaca basilicão and Gennaro de menta, while the material Grecco à palla reversed the behavior and showed to have more activity of these enzymes at the level of $80 \%$ water availability in the soil.

For proline content, another molecular indicator of stress in plant tissues, significant increases were observed at the level of $60 \%$ water availability in the soil, with increments of $860 \%$, $935 \%$ and $2430 \%$, respectively, for Alfavaca basilicão, Gennaro de menta and Grecco à palla (Figure No. 3D). Among the varieties, Grecco à palla presented the highest production of proline, followed by Gennaro de menta and Alfavaca basilicão, indicating that the material has a highly specialized mechanism for the maintenance of cell turgor, when compared to the other varieties.

Boletín Latinoamericano y del Caribe de Plantas Medicinales y Aromáticas / 98 

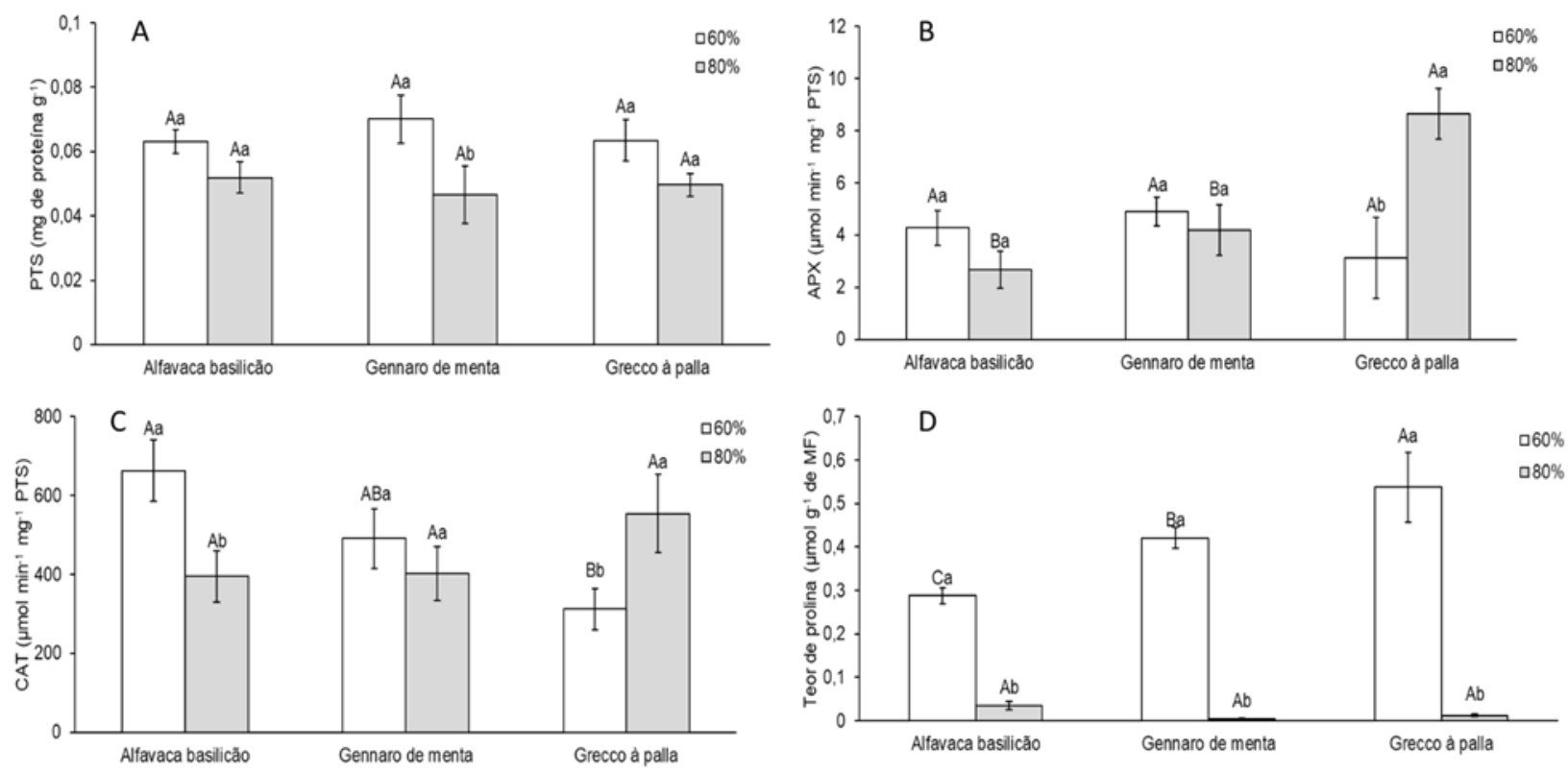

Figure No. 3

Total soluble protein content (A), peroxidase ascorbate (B), catalase (C) and proline content (D) in basil leaves at 75 DAP. Averages followed by the same letter do not differ statistically by the SNK test (5\%). Uppercase letters compare the averages within the water levels, and lowercase letters compare the averages within the varieties

\section{Essential oils}

For the evaluation of essential oils, through the analysis of the main components, relationships or groupings were observed between the variables analyzed, and in this research the primary relationship refers to the investigation of 3 varieties of basil subjected to levels of 60 and $80 \%$ moisture in the soil (Figure No. 4). Thus, considering the main components 1 and 2 , they explain $83.88 \%$ of the variance observed in the experiment. In addition, it is noted that eugenol and linalool were the most expressive compounds for Alfavaca basilicão at the level of $80 \%$ water in the soil and for Grecco à palla under moderate stress.

\section{Gas exchange}

The net carbon assimilation rate (Figure No. 5A), on the second day after the imposition of the water deficit did not show significant interaction, while for the first day after the imposition of the deficit, the variety Grecco à palla showed lower value when submitted to $80 \%$ of the water level of the soil and, on the third day after, Alfavaca basilicão showed a reduction in the assimilation of $\mathrm{CO}_{2}$ to $60 \%$ of the water level of the soil. As for stomatal conductance (Figure No. 5B), it is noted that the varieties showed a behavior similar to the net carbon assimilation rate on the first and third days after the imposition of moderate stress; on the second day, however, the variety Grecco à palla reduced its conductance when in a water deficit state, differing from the results observed for the net carbon assimilation rate.

The results obtained for the rate of leaf transpiration (Figure No. 5C) demonstrate that the variety Grecco a pala after the imposition of the water deficit presented a significant reduction in the condition of moderate stress on the first day, maintained the same rate on the second and presented an increase on the third. The Alfavaca basilicão variety showed no significant difference from the control on the first day after stress was imposed, but decreased significantly over the days. For the efficiency of water use (Figure No. 5D), there was no significant interaction between the factors. Grecco à palla showed similar behavior on the first and third days after the imposition of the water deficit, 
reducing its efficiency to the level of $80 \%$ of water in the soil. On the second day, no significant differences were found, and Alfavaca basilicão demonstrated the same efficiency in the use of water regardless of adverse conditions.

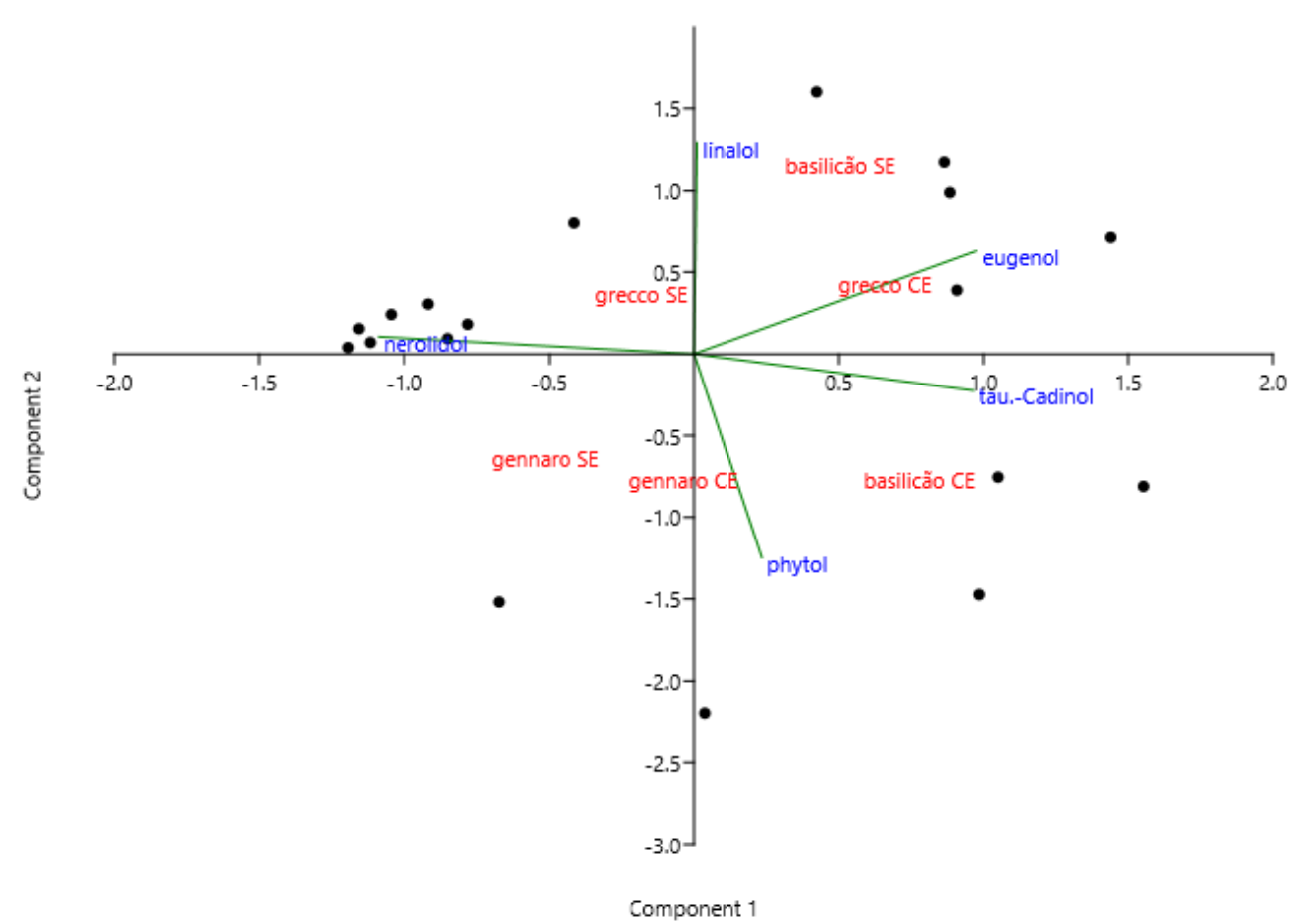

Figure No. 4

Biplot graph for basil varieties submitted to different levels of water in the soil: with stress (CE) or without stress (SE), in relation to the constitution of essential oils

\section{Electrolyte leakage}

The leakage of cellular electrolytes (Figure 6) was greater in plants subjected to water deficit, where damage was observed in the magnitudes, approximately: 29; 30 and $40 \%$ for Alfavaca basilicão, Gennaro de menta and Grecco à palla, respectively, when compared to plants treated with $80 \%$ moisture in the soil.

\section{DISCUSSION}

It is considered that the plants showed completely different behavior during both phenological stages, but that in the joint analysis of the results these experiments highlight the ability of these plants to resume their homeostasis, after being subjected to adverse conditions, demonstrating their characteristics of resilience and adaptation to the environment (Holling, 1973).

In the vegetative phase, all varieties, physiologically, showed good homeostatic behavior, as they managed to regulate their leaf water content (Figure No. 1), and the Gennaro de menta material reduced only by $8.1 \%$ under stress, and still managed to keep its RWC stable. The maintenance of homeostasis is directly correlated with the physiological stability of plants in the face of adverse conditions (Souza \& Buckeridge, 2004; CamargoBortolin et al., 2008).

\section{Boletín Latinoamericano y del Caribe de Plantas Medicinales y Aromáticas / 100}



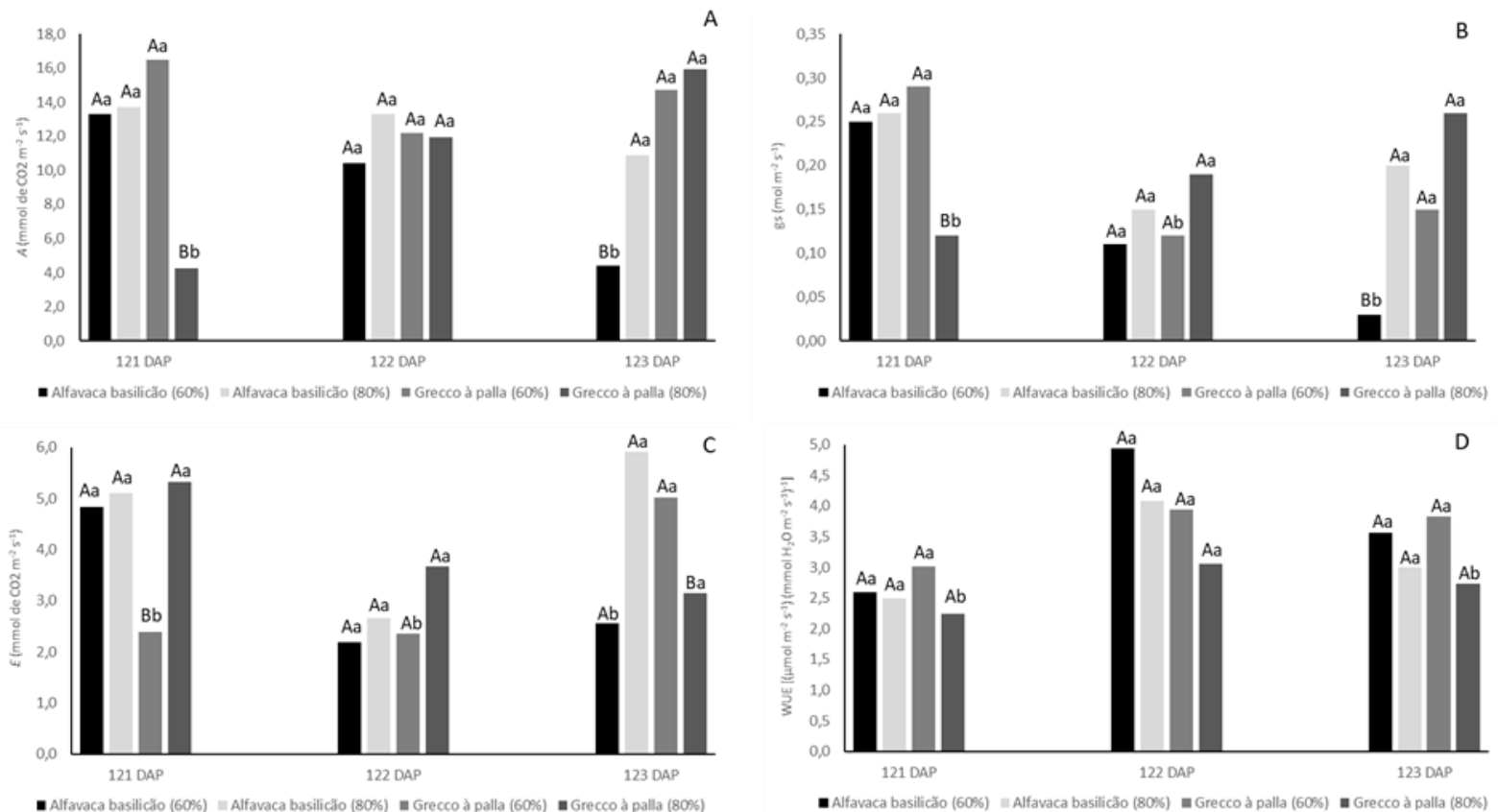

Figure No. 5

Net $\mathrm{CO} 2$ assimilation rate (A, $\mu \mathrm{mol}$ de $\left.\mathrm{CO}_{2} \mathrm{~m}-2 \mathrm{~s}-1\right)(\mathrm{A})$; stomatal conductance (gs, mol m-2 s-1) (B); leaf transpiration (E, $\mu \mathrm{mol}$ de $\left.\mathrm{CO}_{2} \mathrm{~m}-2 \mathrm{~s}-1\right)(\mathrm{C})$ and water use efficiency (WUE, [ $(\mu \mathrm{mol} \mathrm{m}-2 \mathrm{~s}-1)\left(\mathrm{mmol} \mathrm{H}_{2} \mathrm{O} \mathrm{m}-2\right.$

$s-1)-1](D)$, in two varieties of basil after imposing the water deficit at 121, 122 and 123 DAP. Averages followed by the same letter do not differ statistically by the SNK test (5\%). Uppercase letters compare the averages between the water levels, and lowercase letters compare the averages within the varieties

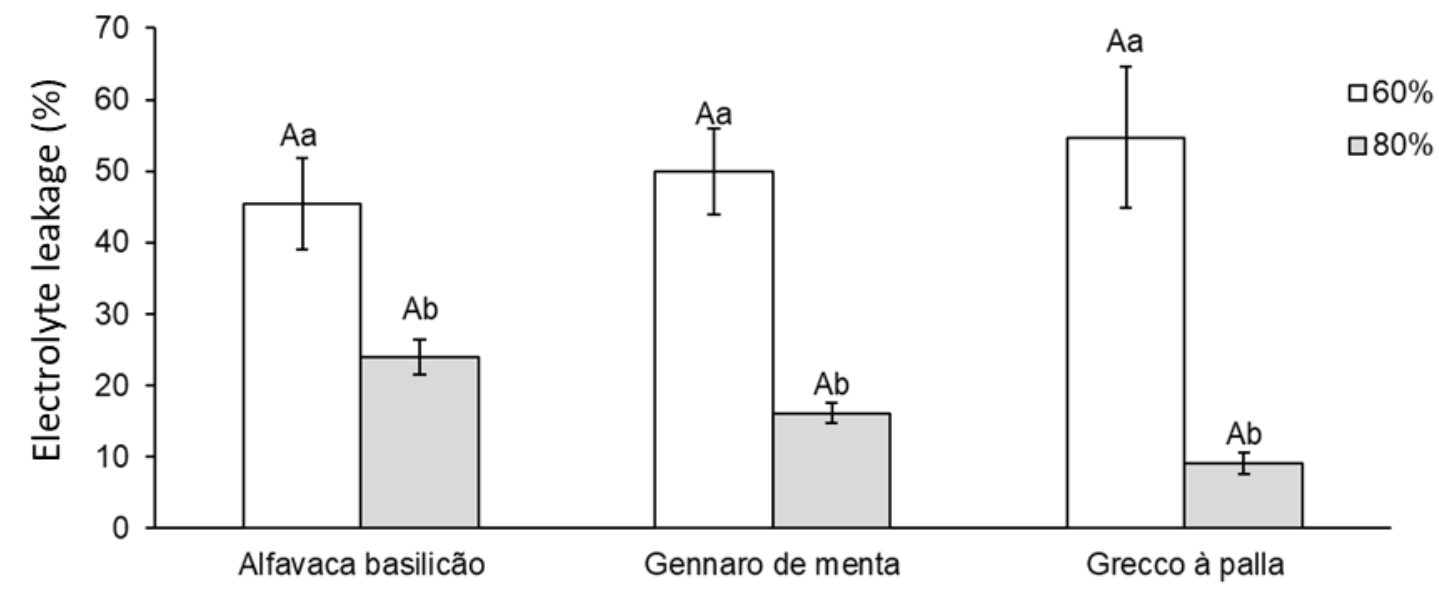

Figure No. 6

Extravasation of electrolytes from the leaves at 120 DAP. Averages followed by the same letter do not differ statistically by the SNK test (5\%). Uppercase letters compare the averages within the water levels, and lowercase letters compare the averages within the varieties 
In the flowering phase, the variety Grecco à palla suffered significant reductions in its leaf water content (Figure No. 1) when exposed to moderate stress, differing from the vegetative phase, indicating that the varieties were not able to maintain homeostasis in these conditions. This fact is evidence that, at this stage, these varieties have a strategy to escape water stress through morphophysiological changes (Galle et al., 2011; Kloeke et al., 2012), such as leaf fall and flower abortion, rather than the tolerance strategy. According to Santos and Carlesso (1998), when plants are subjected to water deficit at the beginning of their cycle, they are more easily able to adapt to the conditions imposed.

The results indicate that the lack of water reduces the cellular water status, however the Gennaro de menta material showed physiological aptitude to support the water deficit, these reductions in basil RWC due to water stress were also reported by Radácsi et al. (2010), who, studying different levels of field capacity (70, 50 and $30 \%$ ), found that the condition of greater water stress resulted in a $20 \%$ decrease in RWC, compared to control treatment plants (which received water corresponding to $70 \%$ of the field capacity of the soil).

When exposed to $80 \%$ water, the three varieties showed an increase in the pigment content, or did not show variability if subjected to water reduction, as in the case of Alfavaca basilicão (Figure No. 2), this pattern of adjustment in chlorophyll content as a function of the water level available to plants has already been reported in the culture of $O$. basilicum L. (Khalid et al., 2006),

The reduction in the levels of photosynthetic pigments (Figure No. 2) for the Gennaro de menta under conditions of moderate stress is an indication that the genotype has entered a state of water stress (Ashraf \& Harris, 2013), where this reduction occurs due to oxidative damage (Egert \& Tevini, 2002). Similar results were found by Khordi et al. (2013) when working only with a variety of basil under water deficit. Also, according to these authors, the reduction of chlorophyll in response to environmental stresses depends on the genotype of the plant, and this may have influenced the results of the present study, since three varieties of basil were used. Drought can reduce chlorophyll content in species not tolerant to water deficit (Corrêa et al., 1987).

As for the content of total soluble proteins (TSP), the varieties obtained a behavior similar to the
RWC, observed in this research, where only the Genaro de menta reduced its amount to $80 \%$ of water (Figure No. 3). According to Ravi et al. (2020), nonstructural carbohydrates and soluble proteins, can provide protection mechanisms against water stress, by inducing osmotic adjustment of the cell.

Considering the results found, it is possible to infer that these varieties regulated their metabolism in an adequate way to withstand the condition of moderate stress (60\% of water level).

Evaluating the enzymatic antioxidant metabolism (Figure No. 3), it was observed that the variety Grecco à palla was sensitive under the level of $80 \%$ of water in the soil, since the increased activity of the APX enzyme directly reflects the increase in hydrogen peroxide, the substrate for inducing the enzymatic reaction (Shigeoka et al., 2002; Cavalcanti et al., 2007). The results for the activity of the CAT enzyme (Figure No. 3C) indicate that the Alfavaca basilicão, when compared to the other varieties, showed a higher production of reactive oxygen species when under moderate stress conditions, while the variety Grecco à palla showed greater enzymatic activity of CAT under stress-free conditions, which corroborates the results of the current research for the activity of the APX enzyme (Figure No. 3B). According to Greggains et al. (2000), these enzymes are an important primary defense against free radicals generated under stress conditions, being able to degrade $\mathrm{H}_{2} \mathrm{O}_{2}$ and result in water $\left(\mathrm{H}_{2} \mathrm{O}\right)$ and molecular oxygen $\left(\mathrm{O}_{2}\right)$.

Grecco à palla was the variety that showed the highest accumulation of proline when compared to the others (Figure No. 3), which is an amino acid with an osmoprotective function when the plant is under water stress conditions (Bates et al., 1973; Silva et al., 2015; Moura et al., 2016), which can give greater tolerance to the variety. The significant increase in proline content within all varieties in response to water deficit corroborates the results obtained by Khalid (2006), who observed that basil (O. basilicum L.) plants had a significant increase in proline content when subjected to water deficit. According to Mafakheri et al. (2011), this increase in proline content when the plant is subjected to stress is explained by the fact that this amino acid serves as a source of energy, nitrogen and carbon for tissue recovery.

Pirbalouti et al. (2017), also observed similar behavior for this variable, noting that the maximum 
proline content in two basil species $(O$. basilicum and $O$. ciliatum) was obtained when the plants were subjected to water stress corresponding to $30 \%$ of the field capacity. Similarly, Khordi et al. (2013), observed that the levels of proline in basil increased significantly when the plants were subjected to soil moisture equivalent to 60 and $30 \%$ of the field capacity. These authors report that proline is a widely occurring amino acid in higher vegetables, and its accumulation in large quantities in plants is related to the occurrence of environmental stresses, such as drought and salt stress.

It is observed that the varieties showed a significant increase in proline concomitant to the higher percentages of electrolyte leakage. The leakage of electrolytes, according to Bajji et al. (2002), may be a response due to the limitation in photosynthesis, which results in membrane damage at the leaf level, being one of the first signs of stress.

As a defense mechanism (Ashraf \& Foolad, 2007), there is an increase in the concentration of proline, which will act as an osmoregulatory agent.

For essential oils (Figure No. 4), there is an independent gradient, characterized by a positive grouping between tau-caudinol and phytol, while nerolidol has a negative behavior in relation to component 1. Linalool, on the other hand, component most found in basil plants (Radünz, 2004; Carvalho Filho et al., 2006), was antagonistic to phytol, for component 2. These results are due to the distinct availability of water for cultivation, and the diversified metabolism that exists between the varieties of basil, in line with the results observed in this experiment.

It should be noted that, in the same quadrant, linalool and eugenol are identified as the most expressive oils for the Alfavaca basilicão varieties under moderate stress and Grecco à palla without stress. The behavior of medicinal plants, in terms of the production of compounds, such as alkaloids, flavonoids and essential oils, is directly influenced by the water deficit (Bortolo et al., 2009), however, the level and duration of stress are crucial in the responses of these plants, in terms of quality and quantity (Alvarenga et al., 2011).

The results obtained for gas exchange allow us to affirm that, for photosynthesis, two days of water deficit does not provide a condition of water stress for the studied varieties, while 3 days caused the reduction of $\mathrm{CO}_{2}$ assimilation, stomatal conductance and leaf transpiration for the Alfavaca basilicão genotype.

The reduction in net $\mathrm{CO}_{2}$ assimilation after 3 days of water restriction (Figure No. 5) constitutes a physiological response to water deficiency, and concomitant to the reduction of the photosynthetic rate, there is a reduction in the photoassimilated drains (Bueno et al., 2011), there was also a reduction in stomatal conductance (Figure No. 5) after three days of water deficit for Alfavaca basilicão. It is a response where the plant limits the conductance of gases in the leaves in order to preserve reduce its water loss, thus, consequently limiting its photosynthesis (Mutava et al., 2011).

For Flexas et al. (2004), stomatal conductance above $0.2 \mathrm{~mol} \mathrm{~m}^{-2} \mathrm{~s}^{-1}$ represents a situation of good water availability and values below $0.1 \mathrm{~mol} \mathrm{~m}^{-2} \mathrm{~s}^{-1}$ indicate conditions of severe deficit, while values between these two extremes demonstrate a situation of moderate stress. This statement reinforces our results, where Alfavaca basilicão obtained values below $0.1 \mathrm{~mol} \mathrm{~m}^{-2} \mathrm{~s}^{-1}$ on the third day after the imposition of the water deficit, thus characterizing a situation of severe deficit. For leaf transpiration (Figure No. 5), it is noticed that as the soil water becomes scarce, the varieties begin to reduce their transpiration rate, in order to reduce water loss and save water available in the soil, concomitant to the stomata closure (Silva et al., 2015).

As for the efficiency of water use (Figure No. 5 ), under moderate stress, there was no variation proportional to stomatal conductance for the varieties, which indicates that the water deficit may result in better photosynthetic efficiency. This variable is an excellent tool for analyzing water consumption by productivity in plants of medicinal and aromatic interest, and water levels do not necessarily interfere in the productive pattern of basil plants (Ekren et al., 2012)

It is noticed that the Alfavaca basilicão presented the expected pattern for gas exchange, since, when in a situation of water stress the plant reduces its stomatal conductance, transpiration and, consequently, photosynthesis. In contrast, Grecco à palla showed inconclusive responses.

The results obtained in determining the leakage of electrolytes (Figure No. 6) demonstrated that it was higher in all varieties when subjected to the driest condition $(60 \%$ of the water level), corroborating the results obtained by Khordi et al. 
(2013), who concluded that the decrease in soil moisture from 100 to $30 \%$ resulted in an increase of $22 \%$ in the leakage of electrolytes in basil plants. According to Mahajan and Tuteja (2005), the increase in electrolyte leakage is one of the effects of water stress, which indicates dehydration of the protoplasm and can result in disorders in cellular metabolism.

Briefly, during the Ocimum development the plant physiology, biochemistry and metabolism are directly influenced by supply water for crop. In this sense, the irrigation management can contribute to Ocimum better qualitative attributes, according the variability among cultivars, similar discussion was presented by Kalamartzis et al. (2020a), Kalamartzis et al. (2020b) e Nejatzadeh-Barandozi (2020). Basil varieties present distinct physiological and metabolic responses when subjected to water restriction, a behavior also observed in the different phenological stages, with the vegetative phase as the one with greater tolerance to water restriction.

\section{CONCLUSIONS}

The Alfavaca basilicão variety was the most sensitive to water restriction, in the evaluated parameters. The variety Grecco à palla showed greater tolerance to water deficit in the reproductive phase compared to the other varieties, suggesting that the increase in the proline amino acid is an osmoregulator, which contributes to preserve its photosynthetic capacity, and efficient use of water. The Gennaro de menta genotype showed greater sensitivity when exposed to conditions of good water availability. Among the five major metabolic factors evaluated, the most expressive for vegetative phase in the two water levels in the soil were linalool and eugenol, with little participation of nerolidol.

\section{ACKNOWLEDGEMENTS}

This study was partially funded by the Coordenação de Aperfeiçoamento de Pessoal de Nível Superior Brasil (CAPES) - Finance Code 001. And the authors are grateful for the financial support from the National Council for Scientific and Technological Development (CNPq, Conselho Nacional de Desenvolvimento Científico e Tecnológico), and the National Institute of Science and Technology - INCT BioNat, grant \#465637/2014-0, Brazil.

\section{REFERENCES}

Afkari A. 2018. Effects of drought stress and nitrogen fertilizer rate on some physiological characteristics, essential oil percentage, and yield of basil (Ocimum basilicum L.). Iran J Med Aromatic Plant 33: 1047 - 1059.

Alvarenga ICA, Queiroz GA, Honório ICG, Valadares RV, Martins ER. 2011. Prolina livre em alecrim-pimenta sob estresse hídrico antes da colheita. Rev Bras Plant Med 13: 539 - 541. https://doi.org/10.1590/s1516-05722011000500006

Ashraf M, Foolad MR, 2007. Roles of glycine betaine and proline in improving plant abiotic stress resistence. Environm Exp Bot 59: 206 - 216. https://doi.org/10.1016/j.envexpbot.2005.12.006

Ashraf M, Harris PJC. 2013. Photosynthesis under stressfull enviroments: Na overview. Photosynthetica 51: 163 190.

Bajji M, Kinet JM, Lutts S. 2002. The use of the electrolyte leakage method for assessing cell membrane stability as a water stress tolerance test in durum wheat. Plant Growth Regul 36: 61 - 70. https://doi.org/10.1023/a:1014732714549

Bates LS, Waldren RP, Teare ID. 1973. Rapid determination of free proline for water-stress studies. Plant Soil 39: 205 - 207. https://doi.org/10.1007/bf00018060

Basu S, Ramegowda V, Kumar A, Pereira A. 2016. Plant adaptation to drought stress. F1000Research 5: 1554. https://doi.org/10.12688/f1000research.7678.1

Bianchi L, Germino GH, Silva MA. 2016. Adaptação das plantas ao déficit hídrico. Acta Iguazu 5: 24.

Blum A, Ebercon A. 1981. Cell membrane stability as a measure of drought and heat tolerance in wheat. Crop Sci 21: 43 - 47. https://doi.org/10.2135/cropsci1981.0011183x002100010013x

Bradford MM. 1976. A rapid and sensitive method for the quantitation of microgram quantities of protein utilizing the principle of protein-dye binding. Anal Biochem 72: 248 - 274.

https://doi.org/10.1016/0003-2697(76)90527-3

Bortolo DPG, Marques PAA, Pacheco AC. 2009. Teor e rendimento de flavonoides em calêndula (Calendula officinalis L.) cultivada com diferentes lâminas de irrigação. Rev Bras Plant Med 11: 435 - 441. 
https://doi.org/10.1590/s1516-05722009000400012

Bueno ACR, Prudente DA, Machado EC, Ribeiro RV. 2011. Daily temperature amplitude affects the vegetative growth and carbon metabolism of orange trees in a rootstock dependent manner. J Plant Growth Regul 31: 309 - 319. https://doi.org/10.1007/s00344-011-9240-x

Camargo-Bortolin LHG, Prado CHBA, Souza GM, Novaes P. 2008. Autonomy and network modulation of photosynthesis and water relations of Coffea arabica in the field. Rev Bras Fisiol Veg 20: 141 - 151.

Carvalho AMX, Mendes FQ. 2017. SPEED Stat: a minimalist and intuitive spread sheet program for classical experimental statistics. In: Anais da $62^{a}$ Reunião Anual da Região Brasileira da Sociedade Internacional de Biometria, Lavras, Brasil.

Carvalho Filho JLS, Blank AF, Alves PB, Ehlert PAD, Melo AS, Cavalcanti SCH, Arrigoni-Blank MF, Silvamann R. 2006. Influence of the harvesting time, temperature and drying period on basil (Ocimum basilicum L.) essential oil. Rev Bras Farmacogn 16: 24 - 30. https://doi.org/10.1590/s0102-695x2006000100007

Cavalcanti FR, Lima JPMS, Ferreira-Silva SL, Viégas RA, Silveira JAG. 2007. Roots and leaves display contrasting oxidative response during salt stress and recovery in cowpea. J Plant Physiol 164: 591 - 600. https://doi.org/10.1016/j.jplph.2006.03.004

Corrêa AFF, Ranzani G, Ferreira LGR. 1987. Relações entre o déficit hídrico e alguns processos fisiológicos e bioquímicos em quatro clones de seringueira. Acta Amazonica 16/17: 3 - 12. https://doi.org/10.1590/1809-43921987171012

Dorni, AIC, Amalraj A, Gopi S, Varma K, Aanjana SN. 2017. Novel cosmeceuticals from plants - An industry guided review. J Applied Res Med Aromatic Plants 7: 1 - 26. https://doi.org/10.1016/j.jarmap.2017.05.003

Dou H, Niu G, Gu M. 2019. Pre-Harvest UV-B radiation and photosynthetic photon flux density interactively affect plant photosynthesis, growth, and secondary metabolites accumulation in basil (Ocimum basilicum) plants. Agronomy 9: 434 - 453. https://doi.org/10.3390/agronomy9080434

Dou H, Niu G, Gu M, Masabni JG. 2018. Responses of sweet basil to different daily light integrals in photosynthesis, morphology, yield, and nutritional quality. HortScience 53: 496 - 503. https://doi.org/10.21273/hortsci12785-17

Egert M, Tevini M. 2002. Influence of drought on some physiological parameters symptomatic for oxidative stress in leaves of chives (Allium schoenoprasum). Environm Exp Bot 48: 43 - 49. https://doi.org/10.1016/s0098-8472(02)00008-4

Ekren S, Sonmez Ç, Ozçakal E, Kurttas YSK, Bayram E, Gurgulu H. 2012. The effect of different irrigation water levels on yield and quality characteristics of purple basil (Ocimum basilicum L.). Agric Water Manag 109: 155 - 161. https://doi.org/10.1016/j.agwat.2012.03.004

Fernandes B, Sykes DJ. 1968. Capacidade de campo e retenção de água em três solos de Minas Gerais. Rev Ceres 15: 1 - 39 .

Flexas J, Bota J, Loreto F, Cornic G, Sharkey TD. 2004. Diffusive and metabolic limitations to photosynthesis under drought and salinity in $C_{3}$ plants. Plant Biol 6: 269 - 279. https://doi.org/10.1055/s-2004-820867

Galle A, Florez-Sarasa I, Aououdad HE, Flexas J, 2011. The Mediterranean evergreen Quercus ilex and the semideciduous Cistus albidus differ in their leaf gas exchange regulation and acclimation to repeated drought and re-watering cycles. J Exp Bot 62: 5207 - 5216. https://doi.org/10.1093/jxb/err233

Greggains V, Finch-Savage WE, Quick WP, Atherton NM, 2000. Metabolism-induced free radical activity does not contribute significantly to loss of viability in moist-stored recalcitrant seeds of contrasting species. New Phytologist 148: 267 - 276. https://doi.org/10.1046/j.1469-8137.2000.00757.x

Hammer O, Harper DA, Ryan DD. 2001. Past: Paleontological statistics software package for education and data analysis. Paleontologia Electronica 4: 5 - 7.

Holling CS. 1973. Resilience and stability of ecological systems. Ann Rev Ecol Syst 4: 1 - 23.

Kalamartzis I, Menexes G, Georgiou P, Dordas C. 2020a. Effect of water stress on the physiological characteristics of five basil (Ocimum basilicum L.) cultivars. Agronomy 10: 1 - 20.

https://doi.org/10.3390/agronomy10071029

Kalamartzis I, Dordas C, Georgiou P, Menexes G. 2020b. The use of appropriate cultivar of basil (Ocimum 
basilicum) can increase water use efficiency under water stress. Agronomy 10: 1 - 16. https://doi.org/10.3390/agronomy10010070

Khalid KA, 2006. Influence of water stress on growth, essential oil, and chemical composition of herbs (Ocimum spp.). Int Agrophys 20: 289 - 296.

Khordi S, Saidi M, Ghanbari F. 2013. Induction of drought tolerance in sweet basil (Ocimum basilicum L.) by salicylic acid. Int J Agric Food Res 2: 18 - 26. https://doi.org/10.24102/ijafr.v2i2.149

Kloeke AEE, Douma JC, Ordoñez JC, Reich PB, Bodegom PM. 2012. Global quantification of contrasting leaf life span strategies for deciduous and evergreen species in response to environmental conditions. Global Ecol Biogeog 21: 224 - 235. https://doi.org/10.1111/j.1466-8238.2011.00667.x

Macedo WR, Kitahara DK, Castro PRC. 2013. Unravelling the physiologic and 256 metabolic action of thiamethoxam on rice plants. Pestic Biochem Phys 107: 244 - 249.

https://doi.org/10.1016/j.pestbp.2013.08.001

Mafakheri A, Siosemardeh A, Bahramnejad A, Struik PC, Sohrabi Y. 2011. Effect of drought stress and subsequent recovery on protein, carbohydrate contents, catalase and peroxidase activities in three chickpea (Cicer arietinum) cultivars. Crop Sci 5: 1255 - 1260.

Mahajan S, Tuteja N. 2005. Cold, salinity and drought stresses: an overview. Arch Biochem Biophys 444: 139 158.

Moura AR, Nogueira RJMC, Silva JAA, Lima TV. 2016. Relações hídricas e solutos orgânicos em plantas jovens de Jatropha curcas L. sob diferentes regimes hídricos. Ciência Florestal 26: 345 - 354. https://doi.org/10.5902/1980509822735

Mutava RN, Prasad PVV, Tuinstra MR, Kofoid KD, Yu J. 2011. Characterization of sorghum genotypes for traits related to drought tolerance. Field Crops Res 123: 10 - 18. https://doi.org/10.1016/j.fcr.2011.04.006

Nakano Y, Asada K. 1981. Hydrogen peroxide is scavenged by ascorbate-specific peroxidase in spinach chloroplasts. Plant Cell Physiol 22: 867 - 880. https://doi.org/10.1093/oxfordjournals.pcp.a076232

Nejatzadeh-Barandozi, F. 2020. Effects of different levels of mulch and irrigation on growth traits and essential oil content of basil. Ital J Agron 15: 222 - 228. https://doi.org/10.4081/ija.2020.1247

Omidbaigi R, Hassani A, Sefidkon F. 2003. Essential oil content andcomposition of sweet basil (Ocimum basilicum) at different irrigation regimes. J Essent Oil Bear Plants 6: 104 - 108.

https://doi.org/10.1080/0972-060x.2003.10643335

Patel RP, Singh R, Rao BRR, Singh RR, Srivastava A, Lal RK. 2016. Differential response of genotypexenvironment on phenology, essential oil yield and quality of natural aroma chemicals of five Ocimum species. Ind Crops Prod 87: 210 - 217. https://doi.org/10.1016/j.indcrop.2016.04.001

Paton A, Putievsky E. 1996. Taxonomic problems and cytotaxonomic relationships between and within varieties of Ocimum basilicum and related species (Labiatae). Kew Bull 51: 509 - 524.

https://doi.org/10.2307/4117026

Pirbalouti AG, Malekpoor F, Salimi A, Golparvar A. 2017. Exogenous application of chitosan on biochemical and physiological characteristics, phenolic content and antioxidant activity of two species of basil (Ocimum ciliatum and Ocimum basilicum) under reduced irrigation. Scientia Horticult 217: 114 - 122. https://doi.org/10.1016/j.scienta.2017.01.031

Radácsi R, Inotai K, Sározi S, Bernáth J, Németh E. 2010. Effetct of water supply on the physiological characteristic and production of Basil (Ocimum basilicum L.). Eur J Horticult Sci 75: 193 - 197.

Radünz LL. 2004. Efeito da temperatura do ar de secagem no teor e na composição dos óleos essenciais de guaco (Mikania glomerata S.) e hortelã comum (Mentha $\mathbf{x}$ villosa Huds.). Thesis, Universidade Federal de Viçosa, Brazil.

Ravi S, Young T, Macinnis-Ng C, Nyugen T V, Duxbury M, Alfaro A C, Leuzinger S. 2020. Untargeted metabolomics in halophytes: The role of different metabolites in New Zealand mangroves under multifactorial abiotic stress conditions. Environm Exp Bot 173: 103993.

https://doi.org/10.1016/j.envexpbot.2020.103993

Santos RF, Carlesso R. 1998. Déficit hídrico e os processos morfológicos e fisiológicos das plantas. Rev Bras Eng Agríc Amb 2: 287 - 294. https://doi.org/10.1590/1807-1929/agriambi.v2n3p287-294

Boletín Latinoamericano y del Caribe de Plantas Medicinales y Aromáticas / 106 
Shigeoka S, Ishikawa T, Tamoi M, Miyagawa Y, Takeda T, Yabuta Y, Yoshimura K. 2002. Regulation and function of ascorbate peroxidase isoenzymes. J Exp Bot 53: 1305 - 1319. https://doi.org/10.1093/jxb/53.372.1305

Silva J, Villanova VA, Dos Santos DMM. 2015. Temperature stress in accumulation of free proline of pigeonpea seedlings from seeds treated with polyamines. Semina: Ciências Agrárias 36: 103 - 122.

Silveira JAG, Melo ARB, Viégas RA, Oliveira JTA. 2001. Salinity-induced effects on nitrogen assimilation related to growth in cowpea plants. Environm Exp Bot 46: 171 - 179. https://doi.org/10.1016/s0098-8472(01)00095-8

Souza GM, Buckeridge MS. 2004. Sistemas complexos: novas formas de ver a botânica. Rev Bras Bot 27: 407 419. https://doi.org/10.1590/s0100-84042004000300002

Witham FH, Blaydes DF, Devlin RM. 1971. Experiments in plant physiology. D. Van Nostrand Reinhold Co., New York, USA. 